Article

\title{
Enzymatic Potential of Bacteria and Fungi Isolates from the Sewage Sludge Composting Process
}

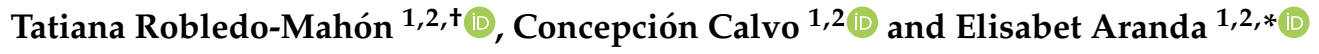 \\ 1 Institute of Water Research, University of Granada, Ramón y Cajal 4, 18071 Granada, Spain; \\ robledo_mahon@af.czu.cz (T.R.-M.); ccalvo@ugr.es (C.C.) \\ 2 Department of Microbiology, Pharmacy Faculty, University of Granada, Campus de Cartuja s/n, \\ 18071 Granada, Spain \\ * Correspondence: earanda@ugr.es \\ + Current address: Department of Agro-Environmental Chemistry and Plant Nutrition, \\ Faculty of Agrobiology, Food and Natural Resources, Czech University of Life Sciences, Kamýcká 129, \\ 16500 Prague 6-Suchdol, Czech Republic.
}

Received: 6 October 2020; Accepted: 2 November 2020; Published: 3 November 2020

Featured Application: Screening of suitable microorganisms adapted to environmental conditions are the challenges for the optimization of biotechnological processes in the current and near future. Some of the isolated microorganisms in this study possess biotechnological desirable features which could be employed in different processes, such as biorefinery, bioremediation, or in the food industry.

\begin{abstract}
The aim of this study was the isolation and characterisation of the fungi and bacteria during the composting process of sewage sludge under a semipermeable membrane system at full scale, in order to find isolates with enzymatic activities of biotechnological interest. A total of 40 fungi were isolated and enzymatically analysed. Fungal culture showed a predominance of members of Ascomycota and Basidiomycota division and some representatives of Mucoromycotina subdivision. Some noticeable fungi isolated during the mesophilic and thermophilic phase were Aspergillus, Circinella, and Talaromyces. During the maturation phase, some lignin modifying enzyme producers, like Purpureocillium, Thielavia, Bjerkandera, or Dichotomyces, were found. Within this group, Thielavia and Bjerkandera showed high activity with production of laccases and peroxidases. In the bacterial culturome, a total of 128 strains were selected and enzymatically analysed. Bacillales, Actinomycetales, Pseudomonadales, and Lactobacillales were the orders most represented in culture-bacteria. Bacillus pumilus, B. stratosphericus, B. safensis, and Pseudomonas formosensis were the species most efficient in enzyme production, particularly peroxidases, polyphenol oxidases ammonifying activity, and amylases. These results showed that sewage sludge composting piles could represent a source of microorganisms which have adapted to adverse conditions.
\end{abstract}

Keywords: bacteria; composting; enzymes; fungi; sewage sludge

\section{Introduction}

Composting is a common process to stabilise sewage sludge, which allows the revalorisation of this waste as amendment. During composting, microorganisms use both extracellular and intracellular enzymes to hydrolyse organic matter and to transform complex compounds into simple molecules that can be assimilated and finally mineralised [1,2]. Enzyme activities are considered as sensor or indicator of the degradation, since they are an indirect measurement of the availability of nutrients, microbial activity, and the physical-chemical conditions. These properties vary depending on the state 
of the compost, on the transformation of organic matter, and on the functional diversity [3-6]. A wide variety of fungi and bacteria are able to break and oxidise macromolecules using a set of hydrolytic, oxidative lyase, and transferase enzymes [7]. In addition, dehydrogenase, $B$ - glucosidase, proteases, phosphatases, and arylsulfatase are the main enzymes proposed to monitor the activity of microbial communities [8].

The associated microbiota during composting is widely diverse and its ecology is extremely complex. Different microbial activities occur depending on the physical-chemical and nutritional conditions prevailing at each moment and throughout the process the microorganisms themselves change the physical-chemical properties. The conditions of the process, like the autochthonous microbiota, temperature, and moisture, or the composition of the sewage sludge, make the pile an interesting ecosystem and a singular environment to search for microorganisms with abilities to produce enzymes with biotechnological applications. Among them, the ones that stand out are those that can be applied in the biosynthesis processes, food industry, biorefineries, and textile industries, like hemicellulases, pectinases, oxidoreductases, laccases, and peroxidases.

Previous studies on microbial diversity have shown that many of the predominant taxa in the different phases of composting possess high capacity to produce enzymes. The study performed by Jurado et al. [9].reported that genera like Alternaria, Cladosporium, Penicillium, Acremonium, Fusarium, and Scopulariopsis for fungi and Bacillus, Brevibacillus, Pseudomonas, Streptomyces, and Cellulosimicrobium for bacteria, isolated from lignocelullosic waste composting, were microorganisms with a high potential for enzyme production [9]. However, as far as we know, there have been no studies about the potential of enzyme production in microorganisms isolated from sewage sludge composting.

In this context, the aim of this study was to isolate fungi and bacteria from different phases of the sewage sludge composting pile built at full-scale and with a semipermeable membrane system, in order to assess the capacity of these isolates as candidates in the production of extracellular enzymes with biotechnological applications. This preliminary study could provide the first step in an interesting approach to find microorganisms with metabolic abilities to degrade micropollutants present in sewage sludge. To reach this objective, a screening of qualitative production of hydrolytic and oxidative enzymes was performed in a collection of isolates from a sewage sludge composting pile.

\section{Materials and Methods}

\subsection{Full-Scale Composting Pile and Sampling}

The sewage sludge composting pile was performed at industrial scale in the Biosolid Plant of "Biomasa del Guadalquivir". This pile was located in Vegas del Genil, Granada (37.160791-3.723879) and it was built using a semipermeable film to cover the pile and a ventilator system, as previously described by Robledo-Mahón et al. [10]. The samples were taken at 5 different depths of the pile $(0,25$, 50,75 and $100 \mathrm{~cm}$ ) and mixed to create a single sample following the composite sample procedure. The samples used in the isolation of microorganisms were from sewage sludge, bulking agent (both as starting material), and at different times: 0 days (initial mixture), 1, 2, 5, 8, 14, 30 (under cover phase), 40, 70 and 120 days (maturation phase).

\subsection{Isolation and Maintenance of Bacteria and Fungi Collection}

To isolate the microbiota by culture-dependent techniques from composting samples, 10 -fold serial dilutions were performed from $1 \mathrm{~g}$ of each sample diluted in $9 \mathrm{~mL}$ of sterile saline solution $(0.9 \%$ $\mathrm{NaCl}$, Carlos Erba Reagents Srl, Barcelona, Spain). Different dilutions were performed $\left(10^{1}-10^{6}\right)$ and $0.1 \mathrm{~mL}$ of each dilution was spread on Petri dishes containing the appropriate medium. Malt extract agar (MEA, VWR-Prolabo Chemicals, Barcelona, Spain) was used for fungi and Tripticase Soya Agar medium (TSA, Thermo Físher Scientific-Oxoid, Madrid, Spain) for bacteria. In MEA, $50 \mu \mathrm{g} \mathrm{L}^{-1}$ of streptomycin and tetracycline were added to inhibit bacterial growth [11,12]. Each dilution was performed in triplicate. The dishes were incubated for $96 \mathrm{~h}$ at $28^{\circ} \mathrm{C}$ and $55^{\circ} \mathrm{C}$ for fungi and $48 \mathrm{~h}$ at $30^{\circ} \mathrm{C}$ 
and $55^{\circ} \mathrm{C}$ for bacteria, in order to distinguish between mesophilic and thermophilic microorganisms. After incubation time, different colonies were selected according to morphotype features and persistence in replicates. Each colony was transferred to a new plate containing the appropriate medium. For long storage of pure cultures, cryovials were prepared using $60 \%$ and $80 \%$ of glycerol for fungi and bacteria, respectively; with two replicates at $-20^{\circ} \mathrm{C}$ and $-80^{\circ} \mathrm{C}$.

\subsection{Determination of Hydrolytic Enzymes}

Proteolytic, amylolytic, phosphatase solubilising, lipolytic, pectinolytic, hemicelullolytic, cellulolytic, and ammonifying activity were determined. The method used was based on the colorimetric changes. Petri dishes containing Potato Dextrose Agar (PDA) for fungi and TSA for bacteria and the corresponding substrate were used. Ammonifying activity was determined in $9 \mathrm{~mL}$ liquid medium using Potato Dextrose Broth (PDB) and Tryptone Soya Broth (TSB) for fungi and bacteria, respectively. The inoculums of fungi were small pieces of mycelium of $0.5 \times 0.5 \mathrm{~mm}$, taken from PDA Petri dishes, incubated approximately $96 \mathrm{~h}$ at $28^{\circ} \mathrm{C}$. The inoculums of bacteria consisted of $30 \mu \mathrm{L}$ of overnighted culture at $30^{\circ} \mathrm{C}$.

Briefly, the substrates used by each enzyme were $1 \%$ of sodium caseinate (ACROS Organics, Madrid, Spain) for proteolytic activity [13]; 1\% of starch (Scharlab SI, Barcelona, Spain) for amylolytic activity [14]; 2.5\% of phosphate tricalcium (PanReac Química S.L.U, Barcelona, Spain) for soluble phosphate solubilizing activity [15]; $1 \%$ of tributiryn (Merck) for lipolytic activity [16]; $0.5 \%$ of pectin (Sigma-Aldrich, Madrid, Spain) for pectinolytic activity [17]; $0.5 \%$ of xylan for hemicellulose activity [18]; $0.5 \%$ of microcrystalline cellulose and $0.005 \%$ of nigrosin for cellulolytic activity [19], and $0.02 \%$ of asparagine (Sigma-Aldrich) for ammonifying activity [20]. Incubation temperatures were $28{ }^{\circ} \mathrm{C}$ for fungi and $30{ }^{\circ} \mathrm{C}$ for bacteria. Incubation time varied depending on the enzymatic activity analysed. Thus, for proteolytic, amylolytic, and phosphate enzyme activity, the microorganisms were incubated 3 days; for lipolytic, pectinolytic, and hemicellulolytic activity 5 days; for cellulolytic activity incubation 7 to 10 days; and for ammonifying activity 15 days. Each determination was performed in triplicate. Positive results were considered after the appearance of a clear halo around the colony growth after the incubation time. In the case of amylolytic activity, it was necessary to add $1-2 \mathrm{~mL}$ of iodine solution to decipher a clear halo around the colony. The results of pectinolytic activity were determined by the addition of $2 \mathrm{~mL}$ of $0.05 \%$ red ruthenium dye solution. This was incubated for $1 \mathrm{~h}$ at room temperature and washed with distilled water. A clear halo around the colony was considered to be a positive result. In the case of ammonifying activity, the addition of $1 \mathrm{~mL} \mathrm{Ne}$ ßler reagent (Sigma-Aldrich) and observing the formation of orange precipitate was necessary. More details are described in Table S1 of the Supplementary Material.

\subsection{Spot Test for Determining Oxidative Enzymes}

The oxidative enzymes assessed in this study were tyrosinase, laccase, peroxidase, and polyphenol oxidase, following the spot test methodology described by Gramss et al. [21]. For that, fungal and bacterial isolates were previously grown in PDA and TSA, respectively. Petri dishes were incubated for $96 \mathrm{~h}$ for fungi and $24 \mathrm{~h}$ for bacteria. The colonized Petri dishes were used for the addition of different solutions by droplets at the edge of each colony: $0.1 \mathrm{M} p$-cresol for tyrosinase, $0.1 \mathrm{M}$ 1-naphthol for laccase, $0.5 \%$ of pyrogallol and $0.5 \%$ of hydrogen peroxide for peroxidase, and $0.5 \%$ of pyrogallol for polyphenol oxidase. Each determination was performed in triplicate. After droplet addition, Petri dishes were incubated $24 \mathrm{~h}$ at $28^{\circ} \mathrm{C}$ and $36^{\circ} \mathrm{C}$ for fungi and bacteria, respectively, to observe colorimetric changes. Changes in the colour of the edge of the colony were considered positive results being yellow-red for tyrosinase, blue-purple for laccase, and brown for peroxidase and polyphenol oxidase. Table S2 supplies detailed information about the preparation and interpretation of the results. 


\subsection{Identification of Fungi and Bacteria by Molecular Techniques}

The phylogenetic identification was performed in the Department of Nucleic Acids of the instrumental techniques laboratory of the University of León (Spain). DNA isolation was performed using PrepMan ${ }^{\mathrm{TM}}$ Ultra (Applied Biosystems, Madrid, Spain) for each selected isolate. The amplification of genes of interest was carried out by PCR in $50 \mu \mathrm{L}$ of reaction with DreamTaq DNA polymerase Kit (Thermo Fisher Scientific, Madrid, Spain) from $1 \mu \mathrm{L}$ of DNA and 20 pmol of each primer. For fungi, the pairs of primers used were ITS1 (5'-TCCGTAGGTGAACCTGCGG-3') and ITS4 (5'-TCCTCCGCTTATTGATATGC-3') [22], to amplify the internal transcriber spacer ITS1 and ITS2, that includes 5.8S rRNA genes. Also, the pair of primers NL1 (5'-GCATATCAATAAGCGGAGGAAAAG-3') and NL4 (5'-GGTCCGTGTTTCAAGACGG-3') of the 28S rRNA gene region were used for yeasts. The pairs of primers used for bacteria were $27 \mathrm{~F}$ (5'-AGAGTTTGATCMTGGCTCAG-3') and 699R (5'-RGGGTTGCGCTCGTT-3') and BA-RF (5'-GACGATCATYTWGGAAACCG-3') and BA-RR (5'-GGNGTYTCRATYGGACACAT-3') [23] to amplify different regions of the bacterial $16 \mathrm{~S}$ rRNA gene. A GeneAmp ${ }^{\circledR}$ PCR System 2700 (Applied Biosystems Thermocycler, Madrid, Spain) was used. The standard PCR program was performed with initial denaturing at $95{ }^{\circ} \mathrm{C}$ for $5 \mathrm{~min}$ for 35 cycles $\left(95^{\circ} \mathrm{C}\right.$ for $30 \mathrm{~s}, 55^{\circ} \mathrm{C}$ for $30 \mathrm{~s}$ and $72{ }^{\circ} \mathrm{C}$ for $1 \mathrm{~min}$ ) with a final extension at $72{ }^{\circ} \mathrm{C}$ for $10 \mathrm{~min}$. PCR products were visualised in $1 \%$ agarose gel and purified using NucleoSpin ${ }^{\circledR}$ Gel and PCR Clean-up Kit (Macherey-Nagel GmbH \& Co., Düren, Germany) according to manufacturer's instructions and were sequenced by BigDye Terminator v3.1 Cycle Sequencing Kit (Applied Biosystems, Madrid, Spain) in capillary automatic sequencer ABI 3130xl (Applied Biosystems, Madrid, Spain). The consensus sequences obtained were edited using the program CHROMAS LITE v.2.0 (Chromas-Technelysium Pty Ltd., Brisbane, Australia) and compared with the sequences in GenBank database using the Basic Local Alignment Search Tool (National Center for Biotechnology Information, U.S. National Library of Medicine, Bethesda, MD, USA) software.

\section{Results}

\subsection{Profile of Extracellular Enzymes Produced by Fungi and Bacteria Isolated during the Composting Process}

A total of 105 fungal strains and 128 bacterial strains were initially isolated. However, in the case of fungi, only 40 could be maintained at laboratory conditions. Consequently, a total of 40 fungal and 128 bacterial strains were tested for hydrolytic and oxidative enzyme activities. The results obtained in the distribution of enzymatic activities are summarised in Figure 1. For fungi (Figure 1A), the most frequent secreted enzymes were amylase $(72.5 \%)$, peroxidase $(47.5 \%)$, polyphenol oxidase $(42 \%)$, pectinase $(42.5 \%)$, cellulase $(32.5 \%)$, and protease $(40 \%)$. In this case, the less frequent activities were tyrosinase and P-solubilising.

(A)

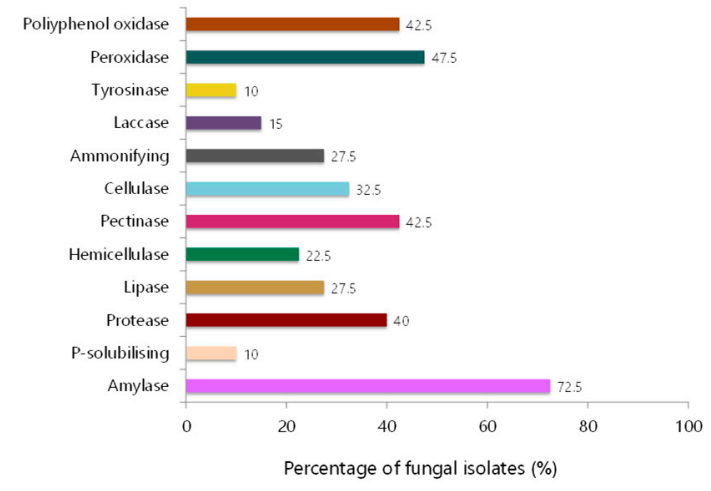

(B)

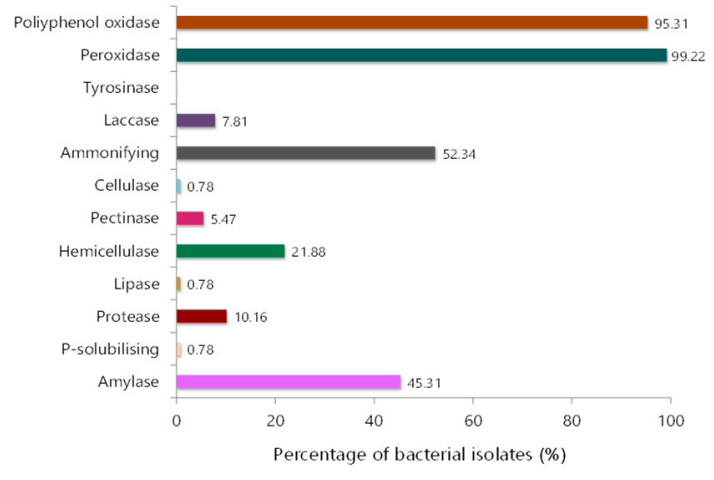

Figure 1. Percentage of enzymes produced by (A) fungal and (B) bacterial isolates. 
In the case of bacteria (Figure 1B), the most frequent activity produced was polyphenol oxidase $(95.3 \%)$ and peroxidase $(99.2 \%)$. As well, ammonifying activity $(52.3 \%)$ was present in more than a half of the bacteria isolated. Amylase was another frequent enzyme $(45.3 \%)$ in bacterial isolates. The less common activities were cellulase, lipase, and P-solubilising.

The distribution of the analysed enzymes along time is shown in Figure 2. In the case of fungi (Figure 2A), amylolytic activity was predominant at the beginning of the process and in the maturation stage. An absence or decrease in the number of isolates producing enzymes between samples 2 and 8 days can be observed. From 14 days, there were more isolates producing enzymes like peroxidase, pectinase, hemicellulose, and tyrosinase, among others. Therefore, the fungal isolates from the initial part of the process and from the maturation stages showed a high number of extracellular enzyme activities.

(A)

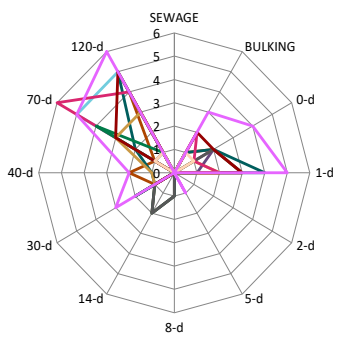

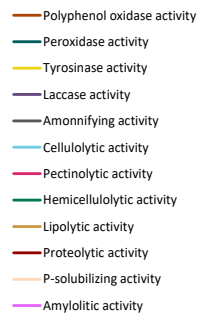

(B)

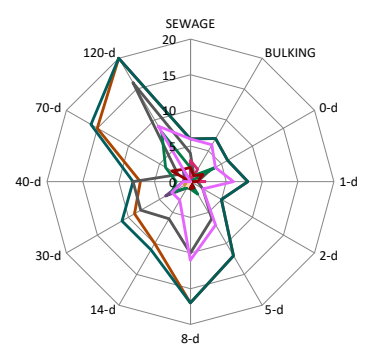

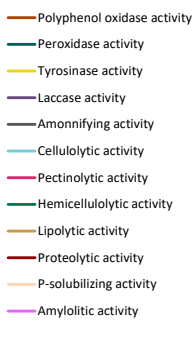

Figure 2. Number of extracellular enzymes produced by fungal (A) and bacterial (B) isolates in each composting sample.

Concerning bacterial isolates, the highest number of activities was found in the isolates belonging to 8,70 and 120 days, being peroxidase and polyphenol oxidase (Figure 2B) followed by ammonifying enzymes and amylases y as the predominant enzymes. The highest number of strains with peroxidase and polyphenol oxidase was at 120 followed by samples at 8 and 70 days. Lignocellulolytic activities like peroxidases and polyphenol oxidase were found in a high number of fungal and bacterial isolates, being mostly isolated from the maturation phase, corresponding to the 70 and 120 day samples.

\subsection{Metabolic Characterisation and Phylogenetic Identification of Fungal Isolates}

For fungal strains, the GenBank accession numbers for the ITS-region and for $28 \mathrm{~S}$ rDNA sequences are MT60989-MT609917. In Figure 3, a detailed heat map with the activities produced by each fungal strain is provided. A total of 105 fungal strains were isolated during composting, but only 40 could be cultured for a long time. A total of 40 fungal strains were identified and metabolically characterised. The phylogenetic study shows high taxonomical diversity, since these isolates belonged to 23 different genera, of which most of them had a single representative. A clear succession was observed within this population with a change in the orders belonging to the early phase under semipermeable film $(0,1,2,5$ and 8 days) corresponding to Sporidiobolales, Saccharomycetales, and Agaricales. During the advanced phase (15 and 30 days), Capnoidales, Trichosporonales, and Mucorales were the most predominant. In the maturation phase (70 and 120 days), these were Hypocreales, Sordariales, and Polyporales. However, the presence of Eurotiales and Microascales was consistent throughout the whole process. 


\begin{tabular}{|c|c|c|c|c|c|c|c|c|c|c|c|c|c|}
\hline \multirow[b]{2}{*}{$\begin{array}{l}\frac{0}{\frac{0}{E}} \\
\text { ต็๊ }\end{array}$} & \multirow[b]{2}{*}{ 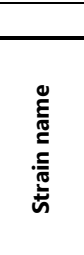 } & \multirow[b]{2}{*}{ Phylogenetic identification } & \multicolumn{4}{|c|}{ Hydrolitic } & \multicolumn{4}{|c|}{ Lignocellulosic } & \multirow[b]{2}{*}{ 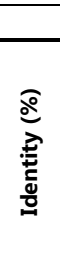 } & \multirow[b]{2}{*}{ 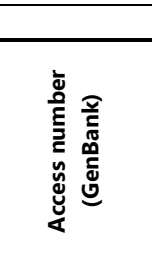 } & \multirow[b]{2}{*}{ Order } \\
\hline & & & $\mid \begin{array}{l}0 \\
0 \\
0\end{array}$ & 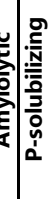 & $\begin{array}{l} \\
\end{array}$ & 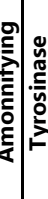 & 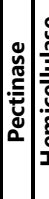 & 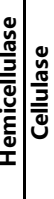 & 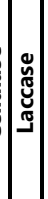 & 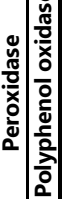 & & & \\
\hline \multirow{5}{*}{ B } & HM01 & Aspergillus tubingensis & & & & & & & & & 100 & KP725001.1 & Eurotiales \\
\hline & $\mathrm{HM} 02$ & Byssochlamys spectabilis & & & & & & & & & 100 & KP725000.1 & Eurotiales \\
\hline & $\mathrm{HM} 03$ & Scopulariopsis brevicaulis & & & & & & & & & 100 & LN850790.1 & Microascales \\
\hline & HM08 & Blastobotrys raffinosifermentans & & & & & & & & & 100 & KP131654.1 & Saccharomycetales \\
\hline & HM09 & Rhodosporidium kratochvilovae & & & & & & & & & 100 & KC442276.1 & Sporidiobolales \\
\hline \multirow{5}{*}{0} & HM10 & Rhodotorula mucilaginosa & & & & & & & & & 94 & LC125991.1 & Sporidiobolales \\
\hline & HM11 & Eurotium chevalieri & & & & & & & & & 99 & HQ728257.1 & Eurotiales \\
\hline & HM12 & Scedosporium aurantiacum & & & & & & & & & 100 & JQ690909.1 & Microascales \\
\hline & HM17 & Aspergillus tubingensis & & & & & & & & & 100 & KP725001.1 & Eurotiales \\
\hline & HM18 & Hormographiella aspergillata & & & & & & & & & 100 & KP132299.1 & Agaricales \\
\hline \multirow{7}{*}{1} & HM19 & Byssochlamys spectabilis & & & & & & & & & 87 & KP725000.1 & Eurotiales \\
\hline & HM22 & Emericella nidulans & & & & & & & & & 100 & KC806056.1 & Eurotiales \\
\hline & HM23 & Tritiratium oryzae & & & & & & & & & 90 & GQ329853.1 & Mucorales \\
\hline & HM28 & Talaromyces purpureogenus & & & & & & & & & 99 & KU981069.1 & Eurotiales \\
\hline & HM29 & Aspergillus versicolor & & & & & & & & & 100 & JX043092.1 & Eurotiales \\
\hline & HM30 & Aspergillus versicolor & & & & & & & & & 100 & GU797139.1 & Eurotiales \\
\hline & HT04 & Lichtheimia ramosa & & & & & & & & & 98 & GQ342877.1 & Mucorales \\
\hline 5 & HM38 & Byssochlamys spectabilis & & & & & & & & & 87 & KP725000.1 & Eurotiales \\
\hline 8 & $\mathrm{HM} 40$ & Cladosporium cladosporioides & & & & & & & & & 100 & HQ829120.1 & Capnodiales \\
\hline \multirow{2}{*}{14} & HM41 & Cladosporium cladosporioides & & & & & & & & & 100 & HQ829120.1 & Capnodiales \\
\hline & $\mathrm{HM} 42$ & Cladosporium cladosporioides & & & & & & & & & 100 & HQ829120.2 & Capnodiales \\
\hline \multirow{3}{*}{30} & HM43 & Scopulariopsis brevicaulis & & & & & & & & & 100 & LN850790.1 & Microascales \\
\hline & $\mathrm{HM} 48$ & Hormographiella aspergillata & & & & & & & & & 100 & KP132299.1 & Agaricales \\
\hline & $\mathrm{HM} 49$ & Trichosporon faecalis & & & & & & & & & 100 & EF153624.1 & Trichosporonales \\
\hline \multirow{2}{*}{40} & HM53 & Circinella $s p$. & & & & & & & & & 87 & KF805760.1 & Mucorales \\
\hline & HM54 & Circinella $s p$. & & & & & & & & & 87 & KF805760.1 & Mucorales \\
\hline \multirow{6}{*}{70} & HM56 & Scopulariopsis brevicaulis & & & & & & & & & 99 & LN850786.1 & Microascales \\
\hline & HM57 & Scopulariopsis brevicaulis & & & & & & & & & 98 & KC311514.1 & Microascales \\
\hline & HM59 & Dichotomomyces cejpii & & & & & & & & & 100 & KF706672.1 & Eurotiales \\
\hline & $\mathrm{HM} 60$ & Purpureocillium lilacinum & & & & & & & & & 99 & KC311490.1 & Hypocreales \\
\hline & HM64 & Aspergillus tubingensis & & & & & & & & & 99 & KP725001.1 & Eurotiales \\
\hline & $\mathrm{HT} 17$ & Scopulariopsis brevicaulis & & & & & & & & & 98 & KC311514.1 & Microascales \\
\hline \multirow{8}{*}{120} & HM65 & Aspergillus versicolor & & & & & & & & & 100 & FJ878627.1 & Eurotiales \\
\hline & HM69 & Acremonium flavum & & & & & & & & & 99 & HQ232037.1 & Hypocreales \\
\hline & HM70 & Thielavia sp. & & & & & & & & & 99 & GU055519.1 & Sordariales \\
\hline & HM71 & Purpureocillium lilacinum & & & & & & & & & 100 & KC157756.1 & Hypocreales \\
\hline & HM74 & Bjerkandera sp. & & & & & & & & & 98 & КТ305937.1 & Polyporales \\
\hline & HM78 & Dichotomomyces cejpii & & & & & & & & & 97 & KF706672.1 & Eurotiales \\
\hline & HM81 & Aspergillus niger & & & & & & & & & 99 & KU323591.1 & Eurotiales \\
\hline & HM82 & Acremonium chrysogenum & & & & & & & & & 98 & U57672.1 & Hypocreales \\
\hline
\end{tabular}

Figure 3. Heat map of the fungal isolates identified and the extracellular profile production for each isolate (blue: positive, yellow: negative). Identity (\%): Percentage of nucleotide identity with the most similar GenBank sequence (Access. number (GenBank)) and order to which each sequence belongs.

Several fungi showed six activities or more, as is shown in Figure 3. Among them, strains identified as Scopulariopsis brevicaulis like HM03, HM43, HM56, HM57, HT17, and HM43 showed positive results for several enzymes. Except the last one, the remaining strains showed positive results for amylolytic, pectinolytic, hemicellulolytic, and cellulolytic activity. The HM03 strain showed peroxidase and polyphenol oxidase activity; three of them also showed proteolytic activity. These species were isolated in different stages of the process. The six strains belonging to $S$. brevicaulis corresponded to the bulking sample and to 30 and 70 days, S. brevicaulis HT17 isolated at $55^{\circ} \mathrm{C}$. 
On the other hand, strains HM18 and HM48 were identified as Hormographiella aspergilatta and showed a high number of enzyme activities, including proteases, amylases, ammonifying enzymes, as well as laccases, peroxidases, and polyphenol oxidase, tyrosinase, pectinases, hemicellulases, and cellulases. Emericella nidulans strain HM22 produced seven enzymatic activities; among them were amylolytic, ammonifying enzymes, tyrosinase, pectinase, hemicellulase, cellulase, laccase, and peroxidase. The strain Aspergillus versicolor HM30 showed a high rate of production of amylase, lipase, ammonifying enzymes, tyrosinase, pectinases, cellulose, peroxidase, and polyphenol oxidase. In the maturation stage, Thielavia sp. HM70 strain with the production of a wide set of lignocellulosic activity was remarkable. In particular, this strain showed nine enzymes, like protease, amylase, ammonifying enzymes and tyrosinase, pectinase, cellulase, laccase peroxidase, and polyphenol oxidase. Bjerkandera sp. HM70 showed positive results in six activities, mostly oxidoreductases like laccase, peroxidase, and polyphenol oxidase. Besides that, it showed hydrolytic activities, like cellulose, protease, and amylase.

In the case of bacteria, a total of 128 strains were tested for enzyme activity production. The strains with the highest number of enzymes in each sample were selected and finally, a total of 34 bacterial strains were molecularly identified. Accession numbers for the 16S rDNA sequences are MT305959-MT305987 for bacterial strains. In this sense, representatives of each composting sample were selected according to the conditions of isolation (mesophile or thermophile), morphotypes (colonies more frequent), and the number of enzymes produced. In Figure 4, the identification of selected bacteria and their extracellular enzymes activities are shown. The results obtained showed that 21 of these 34 bacteria strains belonged to Bacillales, which was the most representative order among the isolates identified and also with the highest number of enzyme activities (six or more). Otherwise, Pseudomonadales was represented by P. formosensis, with a wide number of enzyme activities. Within Actinomycetales, Artrobacter creatinolyticus BM25 and Corynebacterium glutaminicum BM85, between three and four activities were shown. Within Lactobacillales, two strains identified belonged to Enterococcus faecium (BM08 and BT08), with four and five activities, respectively.

B. pumilus, BM02, BM05, and BT02 (Figure 4) showed between six and seven enzymatic activities (proteolytic, amylolytic, pectinolytic, hemicellulolytic, peroxidases, and polyphenol oxidases). B. pumilus BT02 showed six positive results of enzyme activities like protease, amylase, pectinase, hemicellulase, peroxidase, and polyphenol oxidase. In the case of B. pumilus BM02, ammonifying activity was also detected. B. stratosphericus was identified in three strains, corresponding to BM20, BT09, and BM43, with B. stratosphericus BM20 being the strain with the highest number of enzymes showing positive results for pectinolytic, amylolytic, ammonifying, and hemicellulolytic activities, as well as for oxidative enzymes like peroxidase and polyphenol oxidase. Meanwhile, strain BT09 showed the same activities, except for ammonifying enzymes and hemicellulase; the strain BM43 showed the same activities as BM20, apart from amylase activity. B. safensis BM34 showed six positive results for pectinase, amylase, ammonifying enzymes, hemicellulase, peroxidase, and polyphenol oxidase. P. formosensis was the only species belonging to Pseudomonadales with a high rate of enzyme activities. In this case, both strains, BT47 and BT88, were isolates at $55^{\circ} \mathrm{C}$ and showed positive results for six activities. P. formosensis BT47 showed positive results for amylolytic, ammonifying, pectinolytic activities, laccase, peroxidase, and polyphenol oxidase, and BT88 strain showed the same profile, but with proteolytic activity instead of amylolytic activity. B. mojavensis BM40 and BT64 showed positive results for amylase, hemicellulose, and cellulose activity. 


\begin{tabular}{|c|c|c|c|c|c|c|c|c|c|c|c|c|c|c|}
\hline \multirow[b]{2}{*}{$\frac{\frac{0}{0}}{\frac{0}{E}}$} & \multirow[b]{2}{*}{ 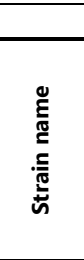 } & \multirow[b]{2}{*}{ Phylogenetic identification } & \multicolumn{5}{|c|}{ Hydrolitic } & \multicolumn{4}{|c|}{ Lignocellulosic } & \multirow[b]{2}{*}{$\begin{array}{l}\text { ఏ } \\
\frac{2}{2} \\
\frac{0}{0} \\
\frac{0}{0}\end{array}$} & \multirow[b]{2}{*}{ 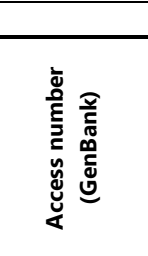 } & \multirow[b]{2}{*}{ Order } \\
\hline & & & $\mid$ & 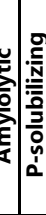 & 离 & 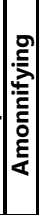 & 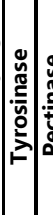 & 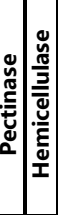 & \begin{tabular}{|l|} 
\\
\\
$\frac{\tilde{c}}{5}$ \\
$\bar{\Xi}$ \\
\end{tabular} & & 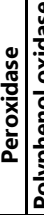 & & & \\
\hline \multirow{3}{*}{ SS } & BM02 & Bacillus pumilus & & & & & & & & & & 99 & KY085970.1 & Bacillales \\
\hline & BM05 & Bacillus pumilus & & & & & & & & & & 99 & JX860616.1 & Bacillales \\
\hline & BT01 & Bacillus paralicheniformis & & & & & & & & & & 99 & MG651169.1 & Bacillales \\
\hline \multirow{2}{*}{ B } & BM08 & Enterococcus faecium & & & & & & & & & & 100 & CP025077.1 & Lactobacillales \\
\hline & BT02 & Bacillus pumilus & & & & & & & & & & 100 & JX860616.1 & Bacillales \\
\hline \multirow{2}{*}{0} & BM20 & Bacillus stratosphericus & & & & & & & & & & 100 & KY797998.1 & Bacillales \\
\hline & BT04 & Bacillus paralicheniformis & & & & & & & & & & 100 & MF928386.1 & Bacillaes \\
\hline \multirow{3}{*}{1} & BM25 & Arthrobacter creatinolyticus & & & & & & & & & & 99 & JN644504.1 & Actinomycetales \\
\hline & BT08 & Enterococcus faecium & & & & & & & & & & 99 & CP025077.1 & Lactobacillales \\
\hline & BT09 & Bacillus stratosphericus & & & & & & & & & & 99 & KY797998.1 & Bacillales \\
\hline \multirow{2}{*}{2} & BT16 & Bacillus licheniformis & & & & & & & & & & 100 & MG546213.1 & Bacillales \\
\hline & BT18 & Bacillus paralicheniformis & & & & & & & & & & 100 & MG651169.1 & Bacillales \\
\hline \multirow{3}{*}{5} & BM34 & Bacillus safensis & & & & & & & & & & 99 & CP018100.1 & Bacillales \\
\hline & BM40 & Bacillus mojavensis & & & & & & & & & & 100 & MF040286.1 & Bacillales \\
\hline & BT23 & Bacillus beijingensis & & & & & & & & & & 99 & NR_117988.1 & Bacillales \\
\hline \multirow{4}{*}{8} & BM43 & Bacillus stratosphericus & & & & & & & & & & 100 & KY797998.1 & Bacillales \\
\hline & BM50 & Bacillus beijingensis & & & & & & & & & & 99 & NR_117988.1 & Bacillales \\
\hline & BT29 & Bacillus paralicheniformis & & & & & & & & & & 99 & MG651169.1 & Bacillales \\
\hline & BT30 & Bacillus paralicheniformis & & & & & & & & & & 99 & CP023168.1 & Bacillales \\
\hline \multirow{3}{*}{14} & BM60 & Virgibacillus halodenitrificans & & & & & & & & & & 99 & CP017962.1 & Bacillales \\
\hline & BM65 & Virgibacillus halodenitrificans & & & & & & & & & & 99 & CP017962.1 & Bacillales \\
\hline & BT37 & Bacillus licheniformis & & & & & & & & & & 100 & MG593200.1 & Bacillales \\
\hline \multirow{4}{*}{30} & BM70 & Serpens flexibilis & & & & & & & & & & 98 & KP973996.1 & Pseudomonadales \\
\hline & BM73 & Bacillus paralicheniformis & & & & & & & & & & 100 & СР023168.1 & Bacillales \\
\hline & BT47 & Pseudomonas formosensis & & & & & & & & & & 100 & NR_118141.1 & Pseudomonadales \\
\hline & BT57 & Pseudomonas formosensis & & & & & & & & & & 100 & NR_118141.1 & Pseudomonadales \\
\hline \multirow{2}{*}{40} & BM85 & Corynebacterium glutamicum & & & & & & & & & & 99 & СР013991.1 & Actinomycetales \\
\hline & BT64 & Bacillus mojavensis & & & & & & & & & & 100 & KY131800.1 & Bacillales \\
\hline \multirow{2}{*}{70} & BM96 & Pseudomonas formosensis & & & & & & & & & & 100 & "NR_118141.1 & Pseudomonadales \\
\hline & BM100 & Psychrobacter pulmonis & & & & & & & & & & 99 & KU364016.1 & Pseudomonadales \\
\hline \multirow{4}{*}{120} & BM106 & Pseudomonas formosensis & & & & & & & & & & 99 & "NR_118141.1 & Pseudomonadales \\
\hline & BM110 & Pseudomonas formosensis & & & & & & & & & & 99 & NR_118141.1 & Pseudomonadales \\
\hline & BT87 & Pseudomonas formosensis & & & & & & & & & & 99 & NR_118141.1 & Pseudomonadales \\
\hline & BT88 & Pseudomonas formosensis & & & & & & & & & & 99 & NR_118141.1 & Pseudomonadales \\
\hline
\end{tabular}

Figure 4. Heat map of the bacterial isolates identified and the extracellular profile production for each isolate (blue: positive, yellow: negative). Identity (\%): Percentage of nucleotide identity with the most similar GenBank sequence (Access. number (GenBank)) and order to which each sequence belongs.

\section{Discussion}

Composting is an oxidative process performed by microorganisms in which the temperature can reach $70^{\circ} \mathrm{C}$. This microbiota is strongly influenced by the microorganisms present in the starting material and the operational conditions, among other factors. In this study, a full-scale composting pile was built at industrial scale using a semipermeable cover connected with a ventilation system. Previous studies have observed that the temperature under these conditions can be higher than $80^{\circ} \mathrm{C}$ at 8 days of the process $[10,24]$ becoming an interesting ecosystem for fungi and bacteria able to resist high temperatures. In this study, a total of 105 fungal strains and 128 bacterial strains were initially isolated. However, in the case of fungi, only 40 could be maintained at laboratory conditions. The number of lost isolates could be explained because it is difficult to reproduce the same nutritional conditions of the pile in the laboratory with synthetic media.

All the strains were tested for hydrolytic and oxidative enzymes. The results showed a high percentage of isolates able to produce enzymes like polyphenol oxidase, peroxidase, amylase, and ammonifying enzymes, these being, the most frequent enzymes in the total of isolates. 
For fungi, amylase was the most frequent enzyme, together with polyphenol oxidase and peroxidases, and, to a lesser extent, pectinase and protease. The number of isolates able to produce amylases was higher in the bulking agent (made of chips from the crushing and vegetable biomass from gardens) and in the samples at 0 and 1 day of composting. After that, the fungal strains isolated over 2, 5 and 8 days (corresponding with the highest temperature in the pile under cover stage) did not show high enzyme production. However, fungal strains isolated at 30, 70 and 120 days, showed a high number of lignocellulosic enzymes. This may be explained because these isolates were present also in the bulking agent and could be more active in mesophilic conditions. Isolates from the maturation stage showed a similar enzymatic profile compared to those isolated from the first phase of composting.

In the case of bacteria, polyphenol oxidase and peroxidase were the most predominant enzymes, confirming the role of these microorganisms in lignin degradation and their contribution to the humification process. It is well-known that ligninolytic enzymes, due to their non-specificity, are involved in the degradation of numerous recalcitrant aromatic compounds, such as hydrocarbons and emerging pollutants, dyes, and BTEX (benzene, toluene, ethylbenzene and xylene) [25,26]. These enzymes could also be involved in the removal of recalcitrant compounds frequently present in sewage sludge, such as pharmaceutical active compounds and polycyclic aromatic hydrocarbons, among others. Ammonifying activity was present in more than half of the bacterial isolates, which indicated the ability of the isolates in transformation of organic nitrogen to ammonium [27]. As well, few bacterial strains isolated between $0-5$ days showed hemicellulolytic and amylolytic activities.

Regarding the distribution in the number of activities according to the composting time, our results suggest that some phases of composting can be more favourable in finding microorganisms with particular metabolic requirements and they can produce these enzymes in a different range of temperatures. A higher number of fungal isolates from the first stage and maturation stage were characterised by amylolytic, hemicellulolytic, and proteolytic activity, meanwhile, for bacteria, there were more isolates from the middle stage and maturation stage characterised by lignocellulosic enzymes.

Among the fungi, Aspergillus and Scopulariopsis had the highest number of strains and were isolated at different sampling times. The most frequent fungi isolated under semipermeable film were Aspergillus, Circinella (saprotrophic and nematophagues fungi), and Talaromyces. They have been described as fungi responsible for organic matter degradation in the thermophile phase due to their resistance to high temperatures $\left(50-65^{\circ} \mathrm{C}\right)$. These filamentous fungi belong to Hypocreales, Sordariales, and Microascales or orders with high representation in the mesophilic and thermophilic phases. A similar dynamic was described by Ryckeboer et al. [28], where members of Aspergillus, Scopulariopsis, and Acremonium, characterised this process. In this study, Aspergillus versicolor HM30 was isolated at the beginning of the process, a common inhabitant in all the environments. Previous studies have reported xylanase production by this species and its potential to bioaccumulate heavy metals and degrade dyes in water effluents [29,30]. All of these fungi, except Scopulariopsis, Coprinopsis (Hormographiella), and Trichosporon, have been identified in composting processes using pyrosequencing techniques [31]. However, S. brevicaulis has been isolated in the composting of lignocellulosic material, in the mesophilic and thermophilic phases [9]. This species has been recently described as degrader of polycyclic aromatic hydrocarbons (PAHs) like anthracene and described as a thermotolerant fungus [32,33]. In this pile, fungi such as Hormographiela aspergilatta and Emericella nidulans have not been previously described in the sewage sludge composting process and they showed a high number of enzymes. Hormographiela aspergilatta, an opportunist pathogen related to complications in patients undergoing treatments for lung diseases [34], could not be considered as a GRAS microorganism (Generally Recognised as Safe). However, its enzymes could be used from previous extraction or genetic engineering. As well, Emericella nidulans HM22 produced all the enzymes studied. The ability of this species to produce enzymes involved in cellulose degradation, like xylanase, has been reported previously [35]. This species has been isolated from soil and is considered a thermotolerant fungus, and could be regarded as a species with a potential biotechnological application and a good candidate for further studies. 
It is interesting to note the presence in the maturation stage of Thielavia and Bjerkandera sp. Thielavia sp. HM70 showed positive results for nine enzymes, four of them corresponding to lignocellulosic enzymes. Thielavia is an ascomycete fungus that includes mesophilic and thermophilic species able to secrete up to five types of laccases [36,37]. Bjerkandera sp. HM70 was also identified in the maturation stage. This fungus is a white rot fungus, whose whole genome has been sequenced and it is characterised by the presence of a broad set of enzymatic activities, mainly peroxidases such as versatile peroxidase, manganese peroxidase, and inducible laccases in the presence of lignocellulosic material [38].

Concerning bacteria, E. faecium (strains BM08 and BT08) showed a remarkable activity. This bacteria has been widely isolated from water and soil samples and has been reported as an efficient degrader of aromatic compounds [39]. Bacillus was identified in several strains during the process. B. pumilus, BM02, BM05, and BT02 had a higher number of activities like proteolytic, amylolytic, pectinolytic, hemicellulolytic, peroxidase, and polyphenol oxidase. These results are in accordance with previous studies in which B. licheniformis and B. pumilus were described as polyphenol oxidase and peroxidase producers [40]. These strains showed a broad metabolic profile and have been previously characterised by their ability to produce peroxidases and proteases. The wide range of temperatures (present also in the thermotolerant range) and $\mathrm{pH}$ in which Bacillus can growth, increase their biotechnological applications [25,41]. As well, B. safensis BM34 showed a wide set of enzymes similar to B. pumilus. Recent studies have shown its potential to produce proteases, in particular alkaline proteases and their application in the detergent industry [42]. B. mojavensis showed only positive results for three enzymes but was isolated in a thermotolerant range. The effectiveness of $B$. mojavensis with the production of different enzymatic activities, like amylases and proteases in a thermophile range, has been previously reported [43]. Also, other studies have demonstrated their ability to produce lignocellulolytic enzymes like xylanase, which was not determined in our study [44,45].

Bacillus is a well-known genus present in composting processes [46-48], and this study showed the production of a broad numerous of extracellular enzymes. In addition, Bacillus species are known for their ability to tolerate high temperatures, in part, due to their ability to form spores. This genus has been widely described as a predominant genus in composting and is able to produce hemicellulolytic enzymes at $50^{\circ} \mathrm{C}[49]$.

\section{Conclusions}

In this study we demonstrated that a real composting pile under semipermeable cover represents an interesting source of microorganisms with metabolic features of biotechnological interest. More studies are necessary to quantify, characterize, and purify theses enzymes for further industrial applications, as well as to investigate the effectiveness of these enzymes in the degradation of recalcitrant compounds.

Supplementary Materials: The following are available online at http://www.mdpi.com/2076-3417/10/21/7763/s1, Table S1. Summary table of methodology used to determine hydrolytic extracellular enzymes. Table S2. Summary table of methodology used to determine oxidative extracellular enzymes.

Author Contributions: Conceptualization, C.C. and E.A.; methodology, T.R.-M.; formal analysis, T.R.-M.; investigation, T.R.-M.; resources, C.C. and E.A.; writing-original draft preparation, T.R.-M.; writing-review and editing, C.C. and E.A.; supervision, C.C. and E.A.; project administration, C.C. and E.A.; funding acquisition, C.C. and E.A. All authors have read and agreed to the published version of the manuscript.

Funding: This research was funded by the Junta de Andalucía, RNM-7370 and CTM2017-84332-R (MINECO/AEI/ FEDER/UE)] and [RYC-2013-12481].

Acknowledgments: E.A. would like to thank the Ministry of Economy and Competitiveness (MINECO) and the European Regional Development Fund (ERDF) for their funds [RYC-2013-12481]. We would like to acknowledge the Environmental Microbiology Research Group (RNM-270) of the University of Granada (Spain).

Conflicts of Interest: The authors declare no conflict of interest. 


\section{References}

1. He, Y.; Xie, K.; Xu, P.; Huang, X.; Gu, W.; Zhang, F.; Tang, S. Evolution of microbial community diversity and enzymatic activity during composting. Res. Microbiol. 2013, 164, 189-198. [CrossRef] [PubMed]

2. Hernández, T.; Masciandaro, G.; Moreno, J.I.; García, C. Changes in organic matter composition during composting of two digested sewage sludges. Waste Manag. 2006, 26, 1370-1376. [CrossRef] [PubMed]

3. Castaldi, P.; Garau, G.; Melis, P. Maturity assessment of compost from municipal solid waste through the study of enzyme activities and water-soluble fractions. Waste Manag. 2008, 28, 534-540. [CrossRef] [PubMed]

4. Cayuela, M.L.; Mondini, C.; Sánchez-Monedero, M.A.; Roig, A. Chemical properties and hydrolytic enzyme activities for the characterisation of two-phase olive mill wastes composting. Bioresour. Technol. 2008, 99, 4255-4262. [CrossRef] [PubMed]

5. Mondini, C.; Fornasier, F.; Sinicco, T. Enzymatic activity as a parameter for the characterization of the composting process. Soil Biol. Biochem. 2004, 36, 1587-1594. [CrossRef]

6. Ros, M.; García, C. A full-scale study of treatment of pig slurry by composting: Kinetic changes in chemical and microbial properties. Waste Manag. 2006, 26, 1108-1118. [CrossRef] [PubMed]

7. Pérez, J.; Muñoz-Dorado, J.; de la Rubia, T.; Martínez, J. Biodegradation and biological treatments of cellulose, hemicellulose and lignin: An overview. Int. Microbiol. 2002, 5, 53-63. [CrossRef]

8. Mohammadi, K.; Heidari, G.; Khalesro, S.; Sohrabi, Y. Soil management, microorganisms and organic matter interactions: A review. Afr. J. Biotechnol. 2011, 10, 19840-19849. [CrossRef]

9. Jurado, M.; López, M.J.; Suárez-Estrella, F.; Vargas-García, M.C.; López-González, J.A.; Moreno, J. Exploiting composting biodiversity: Study of the persistent and biotechnologically relevant microorganisms from lignocellulose-based composting. Bioresour. Technol. 2014, 162, 283-293. [CrossRef] [PubMed]

10. Robledo-Mahón, T.; Martín, M.A.; Gutiérrez, M.C.; González, I.; Toledo, M.; Aranda, E.; Chica, A.F.; Calvo, C. Sewage sludge composting under semi-permeable film at full-scale: Evaluation of odour emissions and relationships between microbiological activities and physico-chemical variables. Environ. Res. 2019, 108624. [CrossRef]

11. Siles, J.A.; González-Menéndez, V.; Platas, G.; Sampedro, I.; García-Romera, I.; Bills, G.F. Effects of Dry Olive Residue Transformed by Coriolopsis floccosa (Polyporaceae) on the Distribution and Dynamic of a Culturable Fungal Soil Community. Microb. Ecol. 2014, 67, 648-658. [CrossRef] [PubMed]

12. Robledo-Mahón, T.; Aranda, E.; Pesciaroli, C.; Rodríguez-Calvo, A.; Silva-Castro, G.A.; González-López, J.; Calvo, C. Effect of semi-permeable cover system on the bacterial diversity during sewage sludge composting. J. Environ. Manag. 2018, 215, 57-67. [CrossRef]

13. Strauss, M.L.A.; Jolly, N.P.; Lambrechts, M.G.; Van Rensburg, P. Screening for the production of extracellular hydrolytic enzymes by non-Saccharomyces wine yeasts. J. Appl. Microbiol. 2001, 91, 182-190. [CrossRef]

14. Hankin, L.; Anagnostakis, S.L. The Use of Solid Media for Detection of Enzyme Production by Fungi. Mycologia 1975, 67, 597-607. [CrossRef]

15. Nautiyal, C.S. An efficient microbiological growth medium for screening phosphate solubilizing microorganisms. FEMS Microbiol. Lett. 1999, 170, 265-270. [CrossRef]

16. Leuschner, R.G.; Kenneally, P.M.; Arendt, E.K. Method for the rapid quantitative detection of lipolytic activity among food fermenting microorganisms. Int. J. Food Microbiol. 1997, 37, 237-240. [CrossRef]

17. Cotty, P.J.; Cleveland, T.E.; Brown, R.L.; Mellon, J.E. Variation in polygalacturonase production among Aspergillus flavus isolates. Appl. Environ. Microbiol. 1990, 56, 3885-3887. [CrossRef]

18. Janshekar, H.; Haltmeier, T.; Brown, C. Fungal degradation of pine and straw alkali lignins. Eur. J. Appl. Microbiol. Biotechnol. 1982, 14, 174-181. [CrossRef]

19. Kauri, T.; Kushner, D.J. Detection of cellulolytic activity of bacteria and fungi growing on agar surfaces. Biotechnol. Tech. 1988, 2, 149-152. [CrossRef]

20. Pochon, J.; Tardieux, P. Techniques D'analyse en Microbiologie du Sol; Editions de la Tourelle: Saint-Mandé, France, 1962.

21. Gramss, G.; Günther, Th.; Fritsche, W. Spot tests for oxidative enzymes in ectomycorrhizal, wood-, and litter decaying fungi. Mycol. Res. 1998, 102, 67-72. [CrossRef]

22. White, T.J.; Bruns, T.; Lee, S.; Taylor, J. Amplification and direct sequencing of fungal ribosomal RNA genes for phylogenetics. PCR Protoc. Guide Methods Appl. 1990, 18, 315-322. 
23. Ko, K.S.; Kim, J.-M.; Kim, J.-W.; Jung, B.Y.; Kim, W.; Kim, I.J.; Kook, Y.-H. Identification of Bacillus anthracis by rpoB Sequence Analysis and Multiplex PCR. J. Clin. Microbiol. 2003, 41, 2908-2914. [CrossRef]

24. González, I.; Robledo-Mahón, T.; Rodríguez-Calvo, A.; Gutiérrez, M.C.; Martín, M.Á.; Chica, A.F.; Calvo, C. Evolution of the composting process with semi-permeable film technology at industrial scale. J. Clean. Prod. 2016, 115, 245-254. [CrossRef]

25. de Oliveira, P.L.; Duarte, M.C.T.; Ponezi, A.N.; Durrant, L.R. Purification and Partial characterization of manganese peroxidase from Bacillus pumilus AND Paenibacillus sp. Braz. J. Microbiol. 2009, 40, 818-826. [CrossRef]

26. Ellouze, M.; Sayadi, S. White-Rot Fungi and their Enzymes as a Biotechnological Tool for Xenobiotic Bioremediation. Manag. Hazard. Wastes 2016. [CrossRef]

27. Geisseler, D.; Horwath, W.R.; Joergensen, R.G.; Ludwig, B. Pathways of nitrogen utilization by soil microorganisms-A review. Soil Biol. Biochem. 2010, 42, 2058-2067. [CrossRef]

28. Ryckeboer, J.; Mergaert, J.; Coosemans, J.; Deprins, K.; Swings, J. Microbiological aspects of biowaste during composting in a monitored compost bin. J. Appl. Microbiol. 2003, 94, 127-137. [CrossRef]

29. Carmona, E.C.; Fialho, M.B.; Buchgnani, É.B.; Coelho, G.D.; Brocheto-Braga, M.R.; Jorge, J.A. Production, purification and characterization of a minor form of xylanase from Aspergillus versicolor. Process Biochem. 2005, 40, 359-364. [CrossRef]

30. Taştan, B.E.; Ertuğrul, S.; Dönmez, G. Effective bioremoval of reactive dye and heavy metals by Aspergillus versicolor. Bioresour. Technol. 2010, 101, 870-876. [CrossRef] [PubMed]

31. Langarica-Fuentes, A.; Zafar, U.; Heyworth, A.; Brown, T.; Fox, G.; Robson, G.D. Fungal succession in an in-vessel composting system characterized using 454 pyrosequencing. FEMS Microbiol. Ecol. 2014, 88, 296-308. [CrossRef]

32. Godoy, P.; Reina, R.; Calderón, A.; Wittich, R.-M.; García-Romera, I.; Aranda, E. Exploring the potential of fungi isolated from PAH-polluted soil as a source of xenobiotics-degrading fungi. Environ. Sci. Pollut. Res. 2016, 23, 20985-20996. [CrossRef]

33. Mao, J.; Guan, W. Fungal degradation of polycyclic aromatic hydrocarbons (PAHs) by Scopulariopsis brevicaulis and its application in bioremediation of PAH-contaminated soil. Acta Agric. Scand. Sect. B Soil Plant Sci. 2016, 66, 399-405. [CrossRef]

34. Godet, C.; Cateau, E.; Rammaert, B.; Grosset, M.; Moal, G.L.; Béraud, G.; Martellosio, J.P.; Iriart, X.; Cadranel, J.; Roblot, F. Nebulized Liposomal Amphotericin B for Treatment of Pulmonary Infection Caused by Hormographiella aspergillata: Case Report and Literature Review. Mycopathologia 2017, 182, $709-713$. [CrossRef]

35. Kango, N.; Agrawal, S.C.; Jain, P.C. Production of xylanase by Emericella nidulans NK-62 on low-value lignocellulosic substrates. World J. Microbiol. Biotechnol. 2003, 19, 691-694. [CrossRef]

36. Ammann, E.M.; Gasser, C.A.; Hommes, G.; Corvini, P.F.-X. Immobilization of defined laccase combinations for enhanced oxidation of phenolic contaminants. Appl. Microbiol. Biotechnol. 2014, 98, 1397-1406. [CrossRef]

37. Berka, R.M.; Grigoriev, I.V.; Otillar, R.; Salamov, A.; Grimwood, J.; Reid, I.; Ishmael, N.; John, T.; Darmond, C.; Moisan, M.-C.; et al. Comparative genomic analysis of the thermophilic biomass-degrading fungi Myceliophthora thermophila and Thielavia terrestris. Nat. Biotechnol. 2011, 29, 922. [CrossRef]

38. Ruiz-Dueñas, F.J.; Lundell, T.; Floudas, D.; Nagy, L.G.; Barrasa, J.M.; Hibbett, D.S.; Martínez, A.T. Lignin-degrading peroxidases in Polyporales: An evolutionary survey based on 10 sequenced genomes. Mycologia 2013, 105, 1428-1444. [CrossRef]

39. Shen, X.-H.; Zhou, N.-Y.; Liu, S.-J. Degradation and assimilation of aromatic compounds by Corynebacterium glutamicum: Another potential for applications for this bacterium? Appl. Microbiol. Biotechnol. 2012, 95, 77-89. [CrossRef] [PubMed]

40. Mohammad, F.G.; Alireza, T. Isolation and characterization of polyphenol oxidase- and peroxidase-producing Bacillus strains from fully fermented tea Camellia sinensis. World J. Microbiol. Biotechnol. 2007, 23, 1327-1332. [CrossRef]

41. Kumar, C.G. Purification and characterization of a thermostable alkaline protease from alkalophilic Bacillus pumilus. Lett. Appl. Microbiol. 2002, 34, 13-17. [CrossRef] [PubMed]

42. Mhamdi, S.; Bkhairia, I.; Nasri, R.; Mechichi, T.; Nasri, M.; Kamoun, A.S. Evaluation of the biotechnological potential of a novel purified protease BS1 from Bacillus safensis S406 on the chitin extraction and detergent formulation. Int. J. Biol. Macromol. 2017, 104, 739-747. [CrossRef] 
43. Hammami, A.; Fakhfakh, N.; Abdelhedi, O.; Nasri, M.; Bayoudh, A. Proteolytic and amylolytic enzymes from a newly isolated Bacillus mojavensis SA: Characterization and applications as laundry detergent additive and in leather processing. Int. J. Biol. Macromol. 2018, 108, 56-68. [CrossRef] [PubMed]

44. Akhavan Sepahy, A.; Ghazi, S.; Akhavan Sepahy, M. Cost-Effective Production and Optimization of Alkaline Xylanase by Indigenous Bacillus mojavensis AG137 Fermented on Agricultural Waste. Enzym. Res. 2011, 2011. [CrossRef] [PubMed]

45. Fatokun, E.N.; Nwodo, U.U.; Okoh, A.I. Classical Optimization of Cellulase and Xylanase Production by a Marine Streptomyces Species. Appl. Sci. 2016, 6, 286. [CrossRef]

46. Bhatia, A.; Madan, S.; Sahoo, J.; Ali, M.; Pathania, R.; Kazmi, A.A. Diversity of bacterial isolates during full scale rotary drum composting. Waste Manag. 2013, 33, 1595-1601. [CrossRef]

47. de Gannes, V.; Eudoxie, G.; Hickey, W.J. Prokaryotic successions and diversity in composts as revealed by 454-pyrosequencing. Bioresour. Technol. 2013, 133, 573-580. [CrossRef]

48. Watanabe, K.; Nagao, N.; Toda, T.; Kurosawa, N. The dominant bacteria shifted from the order "Lactobacillales" to Bacillales and Actinomycetales during a start-up period of large-scale, completely-mixed composting reactor using plastic bottle flakes as bulking agent. World J. Microbiol. Biotechnol. 2009, 25, 803-811. [CrossRef]

49. Wang, K.; Mao, H.; Li, X. Functional characteristics and influence factors of microbial community in sewage sludge composting with inorganic bulking agent. Bioresour. Technol. 2018, 249, 527-535. [CrossRef]

Publisher's Note: MDPI stays neutral with regard to jurisdictional claims in published maps and institutional affiliations. 